\title{
ANALISIS KEMAMPUAN PENGGUNAAN TEKNOLOGI INFORMASI MAHASISWA DALAM PEMBELAJARAN MATEMATIKA DI ERA PANDEMI COVID-19
}

\author{
S. F. Sihotang1 dan R. Ramadhani² \\ 1,2 Universitas Potensi Utama \\ 1'siti.fatimah.sihotang@gmail.com, 2rahmiramadhani3@gmail.com
}

\begin{abstract}
The Covid-19 pandemic had a major impact on various sectors, including the education sector. All schools and colleges in almost all countries affected by Covid-19 have implemented online learning. After being run for one-year, online learning conditions cannot be considered ideal because there are still various obstacles faced, especially in terms of the students' ability to use information technology. Facts that I found on my campus, there are still many students who find it difficult in terms of applications used and in terms of methods or processes of online learning. Thus, this study aims to analyze the influence of students' ability to use information technology variables on the difficulties experienced by students during online learning with E-learning media assistance in terms of applications used and in terms of learning methods or processes online during mathematics learning in the Covid-19 pandemic outbreak. The research method used in this study is structural equation modelling (SEM) analysis, to test the hypothesis. After conducting the research, the results obtained stated that the most positive and significant impact on students' ability to use information technology, namely the applications used during online learning variable compared to the online learning method or process variables themselves during mathematics learning in the Covid19 pandemic outbreak.
\end{abstract}

Keywords : Covid-19, E-learning, Information Technology, Online learning, Structural Equation Modeling (SEM)

\section{ABSTRAK}

Pandemi Covid-19 berpengaruh besar terhadap berbagai sektor, termasuk sektor pendidikan. Semua sekolah dan perguruan tinggi hampir di semua negara yang terdampak Covid-19 memberlakukan kebijkan pembelajaran dari rumah atau dikenal dengan pembelajaran daring. Setelah dijalankan selama satu tahun, faktanya kondisi pembelajaran daring belum dapat disebut ideal sebab masih terdapat berbagai hambatan yang dihadapi, khususnya dalam hal kemampuan penggunaan teknologi informasi mahasiswa. Fakta di lapangan yang saya temukan di kampus saya sendiri, masih banyak mahasiswa yang merasa kesulitan dalam hal aplikasi yang dipergunakan dan dalam hal cara atau proses pembelajaran daring. Dengan demikian, penelitian ini bertujuan untuk menganalisis pengaruh antara variabel kemampuan penggunaan teknologi informasi mahasiwa terhadap kesulitan yang dialami mahasiswa selama pembelajaran daring dengan bantuan media E-learning dalam hal aplikasi yang dipergunakan dan dalam hal cara atau proses pembelajaran daring selama pembelajaran matematika di era pandemi Covid-19. Metode penelitian yang digunakan dalam penelitian ini dengan bantuan analisis model persamaan struktural atau 
Structural Equation Modeling (SEM) untuk menguji hipotesis. Setelah dilakukan penelitian, diperoleh hasil bahwa variabel yang paling berpengaruh positif dan signifikan terhadap kemampuan penggunaan teknologi informasi mahasiswa adalah aplikasi yang digunakan selama pembelajaran daring dibandingkan dengan variabel cara atau proses pembelajaran daring itu sendiri selama pembelajaran matematika di era pandemi Covid-19.

Kata kunci : Pandemi Covid-19, E-learning, Teknologi Informasi, Pembelajaran Daring, Model Persamaan Struktural

\section{PENDAHULUAN}

\subsection{Apa itu Covid - 19?}

Covid-19 (Coronavirus Disease 2019) adalah penyakit yang disebabkan oleh jenis corona virus baru yaitu Sars-CoV-2, yang dilaporkan pertama kali di Wuhan Tiongkok pada tanggal 31 Desember 2019. Severe acute respiratory syndrome coronavirus 2 (SARS-CoV-2) yang lebih dikenal dengan nama virus Corona adalah jenis baru dari corona virus yang menular ke manusia. Virus ini bisa menyerang siapa saja, seperti lansia (golongan usia lanjut), orang dewasa, anak-anak, dan bayi, termasuk ibu hamil dan ibu menyusui. Corona virus adalah kumpulan virus yang bisa menginfeksi sistem pernapasan. Pada banyak kasus, virus ini hanya menyebabkan infeksi pernapasan ringan, seperti flu. Namun, virus ini juga bisa menyebabkan infeksi pernapasan berat, seperti infeksi paru-paru (pneumonia). Virus ini menular melalui percikan dahak (droplet) dari saluran pernapasan, misalnya ketika berada di ruang tertutup yang ramai dengan sirkulasi udara yang kurang baik atau kontak langsung dengan droplet. Infeksi virus Corona disebut Covid-19 (Corona Virus Disease 2019) dan pertama kali ditemukan di kota Wuhan, China pada akhir Desember 2019. Virus ini menular dengan sangat cepat dan telah menyebar ke hampir semua negara, termasuk Indonesia, hanya dalam waktu beberapa bulan (He, Deng and $\mathrm{Li}, 2020$ ). Untuk merespons Covid-19, Sebagian besar negara menggunakan kombinasi kegiatan pembatasan aktivitas dan gerak masyarakat (dengan melakukan lockdown atau karantina wilayah) diikuti dengan kegiatan mitigasi dengan tujuan untuk menunda lonjakan besar pasien. Sebagian besar strategi tanggapan nasional lain yang diambil oleh banyak kepala negara adalah dengan mencakup berbagai pembatasan tingkat kontak dengan melakukan isolasi diri atau karantina; melakukan promosi langkah - langkah kesehatan masyarakat, seperti : selalu mencuci tangan, memakai masker, menjaga jarak sosial; melakukan penguatan pencegahan dan pengendalian infeksi terhadap fasilitas kesehatan, memberikan perhatian khusus pada fasilitas panti jompo; dan penundaan atau pembatalan pertemuan publik berskala besar (Bedford et al., 2020).

\subsection{Pembelajaran Daring dengan Bantuan E-learning dan Kendala}

Pandemi Covid-19 yang terjadi melanda seluruh dunia hampir setahun belakangan ini, menjadi salah satu kekhawatiran baru bagi seluruh lapisan masyarakat termasuk masyarakat Indonesia, khususnya bagi warga Medan. Pandemi ini menjadi tantangan yang tidak biasa dan belum pernah terjadi sebelumnya karena pandemi yang telah terjadi ini mengubah kebiasaan 
dan seluruh kegiatan para warga. Tidak dapat dibantah, jika adanya pandemi Covid-19 sangat berdampak pada berbagai aspek kehidupan, salah satunya pendidikan. Semua sekolah dan perguruan tinggi diharuskan menjalankan proses kegiatan pembelajaran secara jarak jauh karena kegiatan belajar - mengajar harus tetap berjalan meskipun pengajar dan peserta didik berada di rumah. Akibatnya, pendidik dituntut mendesain pembelajaran dengan memanfaatkan sistem daring (online) dengan bantuan media atau sarana e-learning. Hal Ini sesuai dengan keputusan Menteri Pendidikan dan Kebudayaan Republik Indonesia terkait Surat Edaran Nomor 4 Tahun 2020 tentang Pelaksanaan Kebijakan Pendidikan dalam Masa Darurat Penyebaran Covid-19. Berbagai inisiatif dilakukan untuk memastikan kegiatan belajar tetap berlangsung meskipun tidak adanya sesi tatap muka secara langsung. Teknologi, lebih spesifiknya internet, ponsel pintar, dan laptop sekarang digunakan secara luas untuk mendukung pembelajaran secara daring.

Dalam proses kegiatan belajar - mengajar dengan daring, e-learning merupakan cara yang baru. E-Learning merupakan sebuah proses pembelajaran yang berbasis elektronik. Salah satu media yang digunakan adalah jaringan komputer. Dengan dikembangkannya dijaringan komputer memungkinkan untuk dikembangkan dalam bentuk berbasis web, sehingga kemudian dikembangkan ke jaringan komputer yang lebih luas yaitu internet. Penyajian e-learning berbasis web ini bisa menjadi lebih interaktif tentunya. Sistem e-learning ini tidak memiliki batasan akses, inilah yang memungkinkan perkuliahan bisa dilakukan lebih banyak waktu, bisa dilakukan kapan saja, dan dimana saja.

Pembelajaran elektronik (e-learning) pertama kali diperkenalkan oleh Universitas Illionis di Urbana - Champaign dengan menggunakan sistem instruksi berbasis komputer (Computer - Assisted Instruction) dan komputer bernama PLATO (Programmed Logic for Automatic Teaching Operations) yang telah dikembangkan sejak tahun 1960 (Asdar, Anugrah and Talib, 2019). Sistem pembelajaran e-learning tentunya tidak lepas dari perkembangan teknologi informasi di era Revolusi Industri 4.0. Dengan demikian, sistem pembelajaran e-learning ini merupakan suatu terobosan baru dalam dunia pendidikan yang ikut menyebabkan penggunaan teknologi informasi berkembang denga sangat pesat. Sejalan dengan perkembangan teknologi informasi yang semakin pesat, kebutuhan akan konsep dan mekanisme belajar mengajar berbasis teknologi informasi pun menjadi tidak terelakkan lagi (Simanihuruk et al., 2019; Ramadhani, 2020).

Pengertian e-Learning menurut Allen and Bingham (2016) menyatakan bahwa elearning adalah pembelajaran yang disusun dengan tujuan menggunakan suatu sistem elektronik atau juga komputer sehingga mampu untuk mendukung suatu proses pembelajaran. E-learning adalah suatu proses pembelajaran jarak jauh dengan cara menggabungkan prinsipprinsip didalam proses suatu pembelajaran dengan teknologi (Chandrawati, 2010; Ramadhani et al., 2020). E-learning dapat diartikan sebagai suatu sistem pembelajaran yang digunakan 
sebagai sarana dalam proses belajar mengajar yang dilaksanakan tanpa harus bertatap muka secara langsung antara pendidik dengan mahasiswa/l (Garrison, 2017; Valverde-Berrocoso et al., 2020).

Kelebihan e-Learning antara lain tersedianya fasilitas e-moderating di mana pendidik dan peserta didik dapat berkomunikasi secara mudah melalui fasilitas internet secara regular atau kapan saja kegiatan berkomunikasi itu dilakukan dengan tanpa dibatasi oleh jarak, tempat dan waktu. Kedua, pendidik dan peserta didik dapat menggunakan bahan ajar atau petunjuk belajar yang terstruktur dan terjadual melalui internet, sehingga keduanya bisa saling menilai sampai berapa jauh bahan ajar dipelajari. Ketiga, dapat belajar atau mereview bahan ajar setiap saat dan di mana saja kalau diperlukan, mengingat bahan ajar sudah tersimpan di komputer (Lick Cheok and Wong, 2015; Sarker et al., 2018; Abed, 2019; Coman et al., 2020).

Pada konteks efektifitas pembelajaran jarak jauh, pengetahuan tentang perangkat teknologi dan kemampuan dasar dalam pengoperasian teknologi merupakann literasi teknologi paling dasar yang mendorong dalam menciptkan lingkungan pembelajaran jarak jauh yang lebih efektif. Literasi teknologi dasar mengenai cara penggunaan sistem teknologi perlu dilatihkan dan ditingkatkan agar pembelajaran jarak jauh bisa lebih efektif (Ozdamar-Keskin, Ozata and Banar, 2015). Sejalan dengan itu, Mc. Loughlin (2011), Rahmah (2015) dan Falloon (2020) juga menyatakan bahwa literasi teknologi diharapkan mampu mengembangkan keterampilan belajar yang efektif dengan memanfaatkan lingkungan digital yang kaya akan sumber belajar. Ketika pengajar dan pembelajar memiliki literasi teknologi informasi dasar yang baik, seperti mengenal sistem tekologi dan mampu mengoperasikannya, maka proses pembelajaran jarak jauh bisa berlangsung secara efektif. Lebih lanjut, hal yang sama juga dijelaskan oleh Latip (2020), yakni Interaksi, komunikasi, dan kolaborasi selama pembelajaran jarak jauh pada masa pandemi Covid-19 ini bisa dilakukan dengan menggunakan berbagai cara, diantaranya komunikasi via email, menggunakan fitur chating pada berbagai media sosial, dan melalui platform video conference.

Seiring berjalannya waktu, pemanfaatan e-Learning juga tidak terlepas dari berbagai kekurangan. Pada kenyataannya, pembelajaran dari rumah ini menjadi suatu permasalahan baru di tingkat perguruan tinggi. Bagi dosen dan mahasiswa, sistem pembelajaran daring dianggap membosankan dan kurang adanya interaksi dua arah. Kebanyakan mahasiswa hanya dituntut untuk mengerjakan tugas secara manual lalu difoto dan dikumpulkan kepada dosen lewat media Whatsapp, Telegram, Google Classroom atau pun email. Kegiatan ini tentu mengurangi interaksi langsung antara dosen dan mahasiswa, sehingga berdampak terhadap kemampuan mahasiswa dalam memahami dan menguasai materi ajar yang diberikan oleh dosen. Sebagaimana menurut Yustanti \& Novita (2019), Irwanto (2020), Nortvig, Petersen \& Balle (2018), dan Sarker et al. (2018) pemanfaatan e-Learning menyebabkan kurangnya interaksi antara dosen dan mahasiswa atau bahkan antar mahasiswa itu sendiri. Kurangnya 
interaksi ini bisa memperlambat terbentuknya values dalam proses belajar dan mengajar. Proses belajar dan mengajarnya cenderung ke arah pelatihan daripada pendidikan. Berubahnya peran dosen dari yang semula menguasai teknik pembelajaran konvensional, kini juga dituntut mengetahui teknik pembelajaran yang menggunakan kemampuan teknologi informasi.

Tidak hanya sampai disitu, kendala lain juga ditemukan selama berlangsung nya kebijakan belajar dari rumah. Faktanya, ditemukan berbagai hambatan yang dialami mahasiswa dalam pelaksanaannya selama pembelajaran daring, khususnya bagi mahasiswa yang mengambil mata kuliah Matematika. Di Universitas Potensi Utama, khusunya pada kelaskelas yang saya ajar sendiri, yang tentunya mengambil mata kuliah Matematika, saya masih banyak menemukan mahasiswa yang merasa kesulitan dalam hal penggunaan aplikasi yang dipergunakan selama pembelajaran dilakukan secara daring dengan pemanfaatan e-Learning. Selain itu, persoalan lain yang saya temukan yaitu berkaitan dengan cara atau proses pembelajaran daring itu sendiri. Kebanyakan mahasiswa masih bingung bagaimana memahami soal-soal yang diberikan, walaupun dosen sudah memberikan bahan ajar dan sudah menjelaskan materi yang diajarkan. Apalagi ditambah dengan tuntutan agar mahasiswa mampu menggunakan teknologi informasi dengan konsep e-learning dengan menggunakan media Google Classroom, Whatsapp Grup, serta aplikasi Zoom Meeting. Permasalahan ini sejalan dengan penelitian yang telah dilakukan oleh Hutauruk dan Sidabutar pada tahun 2020. Hutauruk dan Sidabutar (2020) mengambil responden sebanyak 6 orang mahasiswa jurusan Pendidikan matematika yang mewakili beberapa angkatan mahasiswa. Dari hasil penelitian mereka, diketahui terdapat beberapa kendala yang pernah dialami selama pembelajaran daring dalam hal aplikasi yang dipergunakan. Kendala tersebut yakni ketika menggunakan aplikasi Google Classroom. Kendala yang dihadapi ketika menggunakan aplikasi ini adalah susah ketika submit tugas dalam bentuk file word, video, serta kesulitan mendownload bahan ajar maupun tugas dari drive Google Classroom yang diikuti. Annur dan Hermansyah (2020) juga telah melakukan penelitian yang sama terkait kesulitan mahasiswa Pendidikan Matematika dalam pembelajaran daring selama adanya pandemi Covid - 19. Annur dan Hermansyah mengambil sampel terhadap mahasiswa Pendidikan Metematika di STKIP Pamane Talino Ngabang yang mengambil mata kuliah Aljabar Abstrak. Dari hasil penelitian mereka, diketahui bahwa terdapat beberapa kesulitan teknis terkait penggunaan teknologi informasi, salah satunya yakni susahnya dalam mengirim tugas dalam ukuran data yang besar ditambah dengan selama kuliah online terkadang menyulitkan mahasiswa, karena laptopnya kadang lelet jadi harus pakai HP, sementara banyak mahasiswa yang tidak pandai dalam membuka aplikasi Google Classroom dari HP, mereka kesulitan menggunakan aplikasi dengan menu yang lebih kecil Ketika melihat di layer HP tentunya. Kemudian, Mailizar et al., (2020) juga telah melakukan penelitian pada guru matematika tingkat sekolah menengah dan memperoleh hasil bahwa penggunaan e-learning memberikan beberapa hambatan dalam 
pelaksanannya, diantaranya kemampuan peserta didik dan pendidik dalam menggunakan teknologi, keterlibatan kurikulum dalam mendorong efektivitas penggunaan e-learning, khususnya di masa pandemi Covid-19, serta pandangan pendidik terhadap penerapan teknologi dalam pembelajaran. Hasil yang sama diperoleh (König, Jäger-Biela \& Glutsch (2020), Hamid, Sentryo \& Hasan (2020) dan Rahayu et al. (2020) dimana penggunaan elearning tidak berdampak efektif dalam membantu peserta didik memahami materi pembelajaran matematika, memberikan kesulitan tersendiri baik bagi peserta didik dan pendidik dalam menggunakan teknologi, kurangnya dukungan jaringan internet yang memadai sehingga tidak memaksimalkan proses pembelajaran di masa pandemi Covid-19, serta sulitnya para pendidik dalam memberikan pengajaran bersifat abstrak dalam konteks pengajaran berbasis teknologi.

Berdasarkan atas hasil penelitian di atas, maka suatu tantangan tersendiri baik bagi dosen maupun mahasiswa dalam menerapkan e-learning dalam proses pembelajaran, khususnya pembelajaran matematika yang banyak memuat materi bersifat abstrak dan perhitungan. Penggunaan e-learning tidak hanya memberikan dampak positif namun juga tidak jarang memberikan dampak negatif dalam pelaksanaan pembelajaran jika tidak diikuti dengan kemampuan penggunaan teknologi informasi yang baik. Hal ini yang harus dilakukan penelusuran lebih lanjut, bagaiamana kesiapan dan kemampuan penggunaan teknologi informasi mahasiswa dalam menghadapi perubahan proses pembelajaran matematika yang biasanya dilakukan secara tatap muka (face-to-face learning) juga ternyata masih mengalami kesulitan yang berarti baik bagi dosen maupun mahasiswa, terlebih jika ditransformasikan dalam bentuk pembelajaran dengan pemanfaatan e-learning. Pada kondisi ini, para dosen akan dituntut untuk lebih bekerja keras dalam membantu mahasiswa dalam memahami konsep matematika melalui e-learning. Melihat dari hal - hal tersebut, maka perlu dilakukan penelitian lebih lanjut terkait bagaimana keterkaitan kemampuan penggunaan teknologi informasi mahasiswa dalam penerapan pembelajaran matematika jarak jauh berbasis e-learning di era pandemi Covid - 19 saat ini dengan kendala - kendala yang muncul. Dengan demikian, yang menjadi rumusan masalah dalam penelitian ini adalah: 1. Bagaimana pengaruh antara kemampuan penggunaan teknologi informasi mahasiwa terhadap kesulitan yang dialami mahasiswa selama pembelajaran jarak jauh dengan bantuan media e-learning dalam hal aplikasi yang dipergunakan selama pembelajaran matematika di era pandemi COVID-19? 2. Bagaimana pengaruh antara kemampuan penggunaan teknologi informasi mahasiwa terhadap kesulitan yang dialami mahasiswa selama pembelajaran jarak jauh dengan bantuan media elearning dalam hal cara atau proses pembelajaran daring selama pembelajaran matematika di era pandemi COVID-19? 


\section{METODE PENELITIAN}

Jenis penelitian ini adalah ex post facto, yaitu peneliti meneliti peristiwa yang telah terjadi dan kemudian merunut ke belakang untuk mengetahui faktor-faktor yang dapat menimbulkan kejadian tersebut (Sugiyono, 2001). Penelitian ini tergolong penelitian kuantitatif jika dilihat berdasarkan jenis datanya. Penelitian kuantitatif adalah pendekatan ilmiah terhadap pengambilan keputusan yang berangkat dari data, selanjutnya diproses menjadi informasi yang berharga bagi masyarakat ilmiah. Pemrosesan data mentah menjadi informasi yang bermanfaat inilah yang merupakan jantung dari analisis kuantitatif.

Penelitian ini juga merupakan penelitian kuantitatif yang menggunakan kuesioner crosssectional (Fraenkel et al., 2012). Pemilihan pendekatan penelitian ini merujuk pada metode kuantitatif yang dianggap mampu memberikan temuan yang andal, valid, objektif dan dapat digeneralisasikan. Teknik pengumpulan data pada penelitian ini yakni menggunakan kuisioner yang diberikan kepada mahasiswa yang berasal dari mahasiswa jenjang pendidikan strata-1 yang mengambil mata kuliah Matematika (dari berbagai program studi dan dari berbagai semester). Penelitian ini memiliki sampel yang diambil secara random dan berjumlah 300 sampel mahasiswa (150 laki-laki dan 150 perempuan).

Metode penelitian yang digunakan dalam penelitian ini yakni dengan bantuan analisis Model Persamaan Struktural atau Structural Equation Modeling (SEM), yang bisa digunakan untuk menguji hipotesis. Model persamaan struktural yang sering disebut juga dengan istilah Structural Equation Modeling (SEM) merupakan salah satu analisis multivariat yang dapat menganalisis hubungan variabel secara kompleks menjadi satu model sederhana dengan menggabungkan prinsip analisis faktor dan analisis jalur (Ghozali, 2014). Rangkaian proses pengolahan data meliputi pengujian model pengukuran (measurement mode), meliputi uji validitas dan reliabilitas, sementara pengujian model struktural (structural model) meliputi uji signifikansi pengaruh variabel independen atau eksogen terhadap varabel dependen atau endogen. Metode estimasi yang digunakan untuk menguji signifikansi dari konversi diagram alur (path diagram) ke dalam persamaan struktural adalah metode Maximum Likelihood.

\section{HASIL DAN PEMBAHASAN}

\subsection{Teori Dasar Model Persamaan Struktural}

Menurut Solimun (2012) analisis model persamaan struktural yang sering disebut juga dengan istilah Structural Equation Modeling (SEM) merupakan sekumpulan teknik statistik yang memungkinkan dilakukan pengujian sebuah rangkaian hubungan yang relatif rumit secara simultan. Di dalam Structural Equation Modeling (SEM) dapat dilakukan tiga kegiatan secara serempak, yaitu pemeriksaan validitas dan reliabilitas instrumen (setara dengan faktor analisis konfirmatori), pengujian model hubungan antar variabel laten (setara dengan analisis path), dan mendapatkan model yang bermanfaat untuk prediksi (setara dengan model struktural atau 
analisis regresi). Sementara Ferdinand (2000) menjelaskan bahwa Structural Equation Modeling (SEM) adalah penggabungan antara dua konsep statistika, yaitu konsep analisis faktor yang masuk pada model pengukuran (measurement mode) dan konsep regresi melalui model struktural (structural mode). Hal yang sama juga disebutkan oleh Ghozali (2014), yang menjelaskan bahwa sebuah pemodelan model persamaan struktural yang lengkap pada dasarnya terdiri dari Measurement Model dan Structural Model. Measurement Model atau model pengukuran ditujukan untuk mengkonfirmasi sebuah dimensi atau faktor berdasarkan indikator-indikator empirisnya, sementara Structural Mode/ adalah model mengenai struktur hubungan yang membentuk atau menjelaskan kausalitas antara faktor.

Alasan dipilihnya Model Persamaan Struktural dalam penelitiam ini karena variabel yang terlibat dalam analisis data adalah variabel laten yang dibentuk oleh beberapa indikator, yang mana dalam penelitian ini terdapat 3 variabel laten dengan masing-masing indikator, yakni variabel $\mathrm{X} 1$ menyatakan kemampuan penggunaan teknologi informasi mahasiswa (KPIT), variabel X2 menyatakan aplikasi yang digunakan selama pembelajaran daring (APL), dan cara atau proses pembelajaran daring (CPPD). Variabel X1 memiliki 7 indikator, variabel $\mathrm{X} 2$ memiliki 5 indikator, dan variabel Y2 memiliki 6 indikator.

\subsection{Pengujian Model Pengukuran Validitas dan Reliabilitas (Measurement Model Test)}

Pengujian validitas dan reliabilitas dilakukan dengan tujuan untuk menguji apakah variabel-variabel indikator yang digunakan benar-benar signifikan dalam hal mencerminkan variabel konstruk atau laten (sifat convergent validity). Beberapa ukuran yang akan diuji adalah sebagai berikut :

1. Ukuran Standardized Loading Factor (SLF)

2. Ukuran Construct Reliability (CR)

3. Ukuran Average Variance Extracted (AVE)

Sifat convergent validity yang baik ditunjukkan dengan nilai standardized loading factor (SLF) yang tinggi. Hair (2010:678) menyarankan nilai SLF $\geq 0,5$. Ukuran construct reliability (CR) juga merupakan indikator penentu yang menunjukkan baik tidaknya sifat convergent validity. Hair et al. (2010) menyatakan nilai $C R \geq 0,7$ termasuk good reliability, sedangkan nilai CR di antara 0,6 dan 0,7 termasuk acceptable reliability, dengan catatan variabel-variabel indikator menunjukkan validitas yang baik. Ukuran CR dihitung dengan rumus sebagai berikut (Hair et al., 2010).

$$
C R=\frac{\left(\sum_{i=1}^{n} S L F_{i}\right)^{2}}{\left(\sum_{i=1}^{n} S L F_{i}\right)^{2}+\left(\sum_{i=1}^{n} e_{i}\right)}
$$


Sementara Hair et al. (2010)menyatakan nilai AVE $\geq 0,5$ menunjukkan adequate convergence. Ukuran average variance extracted (AVE) dihitung dengan rumus sebagai berikut:

$$
A V E=\frac{\sum_{i=1}^{n} S L F_{i}^{2}}{\sum_{i=1}^{n} S L F_{i}^{2}+\sum_{i=1}^{n} e_{i}} \ldots(2)
$$

Tabel 1 menyajikan nilai SLF dari masing-masing variabel laten kemampuan penggunaan teknologi informasi mahasiswa (X1), aplikasi yang digunakan selama pembelajaran daring (Y1) dan cara atau proses pembelajaran daring (Y2). Sementara Gambar 1 disajikan hasil pengujian model.

Tabel 1 : Nilai SLF Berdasarkan Indikator Variabel Kemampuan Penggunaan Teknologi Informasi Mahasiswa (X1), Aplikasi Yang Digunakan Selama Pembelajaran Daring (Y1) dan Cara Atau Proses Pembelajaran Daring (Y2).

\begin{tabular}{l|c}
\hline Indicator & Standardized Loading Factor (SLF) \\
\hline KPTIM1 & 0.935 \\
KPTIM2 & 0.937 \\
KPTIM3 & 0.943 \\
KPTIM4 & 0.931 \\
KPTIM5 & 0.946 \\
KPTIM6 & 0.931 \\
KPTIM7 & 0.947 \\
APL1 & 0.934 \\
APL2 & 0.937 \\
APL3 & 0.938 \\
APL4 & 0.933 \\
APL5 & 0.939 \\
CPPD1 & 0.943 \\
CPPD2 & 0.935 \\
CPPD3 & 0.942 \\
CPPD4 & 0.938 \\
CPPD5 & 0.944 \\
CPPD6 & 0.946 \\
\hline
\end{tabular}




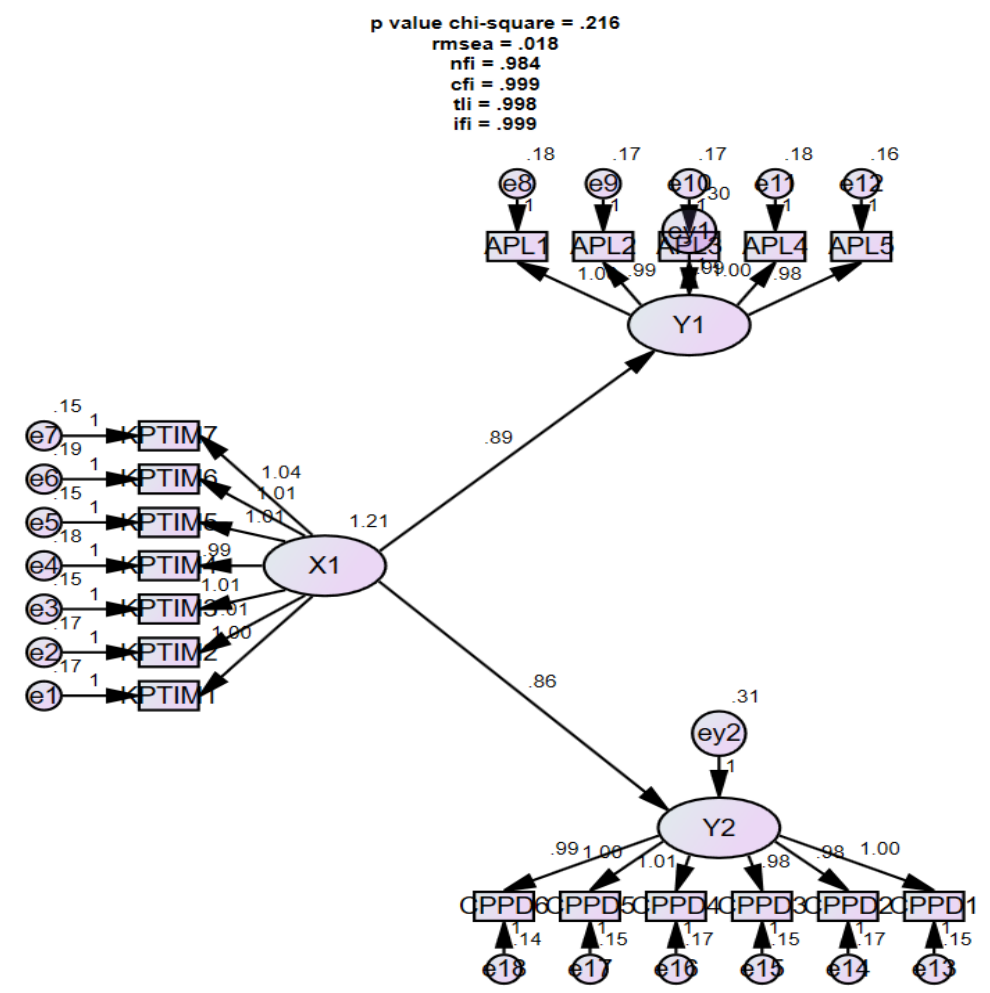

Gambar 1: Hasil Pengujian Model dengan AMOS

Berdasarkan Tabel 1, dapat dilihat bahwa seluruh nilai SLF dari masing-masing indikator $>0,5$. Hal ini menunjukkan bahwa sifat convergent validity yang baik telah dicapai dari sisi ukuran SLF. Selanjutnya Tabel 2 disajikan hasil pengujian validitas berdasarkan average variance extracted (AVE) dan pengujian reliabilitas berdasarkan construct reliability (CR).

Tabel 2 : Pengujian Validitas Average Variance Extracted (AVE) dan Reliabilitas Construct Reliability (CR)

\begin{tabular}{|l|c|c|}
\hline \multicolumn{1}{|c|}{ Latent Variable } & $\begin{array}{c}\text { Average Variance } \\
\text { Extracted (AVE) }\end{array}$ & Construct Reliability (CR) \\
\hline $\begin{array}{l}\text { Kemampuan penggunaan } \\
\text { teknologi informasi mahasiswa } \\
(\mathrm{X} 1)\end{array}$ & 0.882 & 0.981 \\
\hline $\begin{array}{l}\text { Aplikasi yang digunakan selama } \\
\text { pembelajaran daring (Y1) }\end{array}$ & 0.876 & 0.973 \\
\hline $\begin{array}{l}\text { Cara atau proses pembelajaran } \\
\text { daring (Y2) }\end{array}$ & 0.886 & 0.979 \\
\hline
\end{tabular}


Dari ukuran AVE, diketahui nilai AVE, diketahui seluruh nilai $A V E>0.5$, yang berarti telah memenuhi sifat convergent validity yang baik berdasarkan ukuran AVE. Sementara berdasarkan nilai $\mathrm{CR}$, seluruh nilai $\mathrm{CR}>0.7$, yang berarti telah memenuhi sifat convergent validity yang baik berdasarkan ukuran $\mathrm{CR}$.

Kemudian, setelah diketahui bahwa seluruh ukuran nilai SLF, AVE, dan CR terpenuhi, maka dilakukan langkah lebih lanjut untuk melihat kecocokan model secara keseluruhan dengan menggunakan beberapa indikator ukuran kecocokan, yakni P-Value Chi-Square, RMSEA, NFI, CFI, dan TLI. Hasil dari uji kecocokkan model secara keseluruhan dapat dilihat pada Tabel 3.

Tabel 3 : Uji Kecocokkan Model secara Keseluruhan

\begin{tabular}{|c|c|c|c|}
\hline Ukuran Kecocokkan & Nilai & Nilai Patokan & $\begin{array}{c}\text { Kecocokan Model terhadap } \\
\text { Data }\end{array}$ \\
\hline P-Value Chi-Square & 0.216 & $>0.05$ & Ya \\
\hline RMSEA & 0.018 & $<0.1$ & Ya \\
\hline NFI & 0.984 & $>0.9$ & Ya \\
\hline CFI & 0.999 & $>0.9$ & Ya \\
\hline TLI & 0.998 & $>0.9$ & Ya \\
\hline
\end{tabular}

Berdasarkan Tabel 3, didapat hasil bahwa model SEM secara keseluruhan memiliki kemampuan yang baik dalam hal mencocokkan data sampel (good fit).

\subsection{Pengujian Model Struktural (Structural Model Test) Uji Signifikansi (Uji Hipotesis)}

Selanjutnya akan dilakukan pengujian model struktural, yakni menguji signifikansi pengaruh antar variabel, yakni pengaruh antara variabel $X 1$ dengan $Y$ dan variabel $X 2$ dengan Y. Dilanjutkan dengan melihat seberapa besar nilai Koefisien Determinasi dari ke-3 variabel tersebut. Gambar 2 dan 3 disajikan hasil pengujian signifikansi berdasarkan software AMOS.

\begin{tabular}{|c|c|c|c|c|c|}
\hline & Estimate & S.E. & C.R. & $\mathrm{P}$ & Label \\
\hline Y1 <--- X1 & .888 & .041 & 21.895 & 水水 & par 16 \\
\hline $\mathrm{Y} 2<---\quad \mathrm{X} 1$ & .863 & .040 & 21.771 & **** & par 17 \\
\hline
\end{tabular}

Gambar 2 : Pengujian Signifikansi (Uji Hipotesis)

Berdasarkan hasil pada Gambar 2, diketahui beberapa hal berikut :

1. Diketahui kemampuan penggunaan teknologi informasi mahasiswa (X1) berpengaruh positif terhadap aplikasi yang digunakan selama pembelajaran daring (Y1), dengan nilai koefisien jalur sebesar 0,888, dan signifikan, dengan C.R. $=21.895>1,96$ dan $\left.p^{(* * *}\right)<$ 0.001 yang berarti $<0.05$. 
2. Diketahui kemampuan penggunaan teknologi informasi mahasiswa (X1) berpengaruh positif terhadap cara atau proses pembelajaran daring $(Y 2)$, dengan nilai koefisien jalur sebesar 0,863, dan signifikan, dengan C.R. $=21.771>1,96$ dan $p\left({ }^{* \star *}\right)<0.001$ yang berarti $<0.05$.

\begin{tabular}{|l|r|}
\hline & Estimate \\
\hline Y2 & .746 \\
Y1 & .763 \\
\hline
\end{tabular}

Gambar 3: Koefisien Determinasi (R-Square)

Dari Tabel 4 diketahui nilai koefisien determinasi (R-Square) dari variabel aplikasi yang digunakan selama pembelajaran daring $(\mathrm{Y} 1)$ adalah 0,763 , yang berarti variabel kemampuan penggunaan teknologi informasi mahasiswa (X1) mampu mempengaruhi variabel aplikasi yang digunakan selama pembelajaran daring (Y1) sebesar 76,3\%. Diketahui nilai koefisien determinasi (R-Square) dari variabel cara atau proses pembelajaran daring (Y2) adalah 0,746, yang berarti variabel kemampuan penggunaan teknologi informasi mahasiswa (X1) mampu mempengaruhi cara atau proses pembelajaran daring (Y2) sebesar $74,6 \%$.

\section{KESIMPULAN}

Dari hasil pengolahan data yang telah dilakukan, diketahui bahwa variabel yang paling berpengaruh positif dan signifikan terhadap kemampuan penggunaan teknologi informasi mahasiswa adalah aplikasi yang digunakan selama pembelajaran daring dibandingkan dengan variabel cara atau proses pembelajaran daring itu sendiri selama pembelajaran matematika di era pandemi Covid-19. Variabel kemampuan penggunaan teknologi informasi mahasiswa berpengaruh positif terhadap aplikasi yang digunakan dengan nilai koefisien jalur sebesar 0,888 , dan signifikan, dengan nilai C.R. $=21.895$ dan $p$-value sebesar ${ }^{* * *}$, yang berarti lebih kecil dari 0.001 . Hal ini tentu selaras dengan semua asumsi yang telah dipaparkan di atas bahwa kemampuan penggunaan Teknologi Informasi mahasiswa sudah seharusnya ditingkatkan mengingat kunci suksesnya pembelajaran daring adalah mampu mengakses aplikasi online yang dipergunakan dengan baik. Mengingat semakin pesatnya juga perkembangan Teknologi Informasi di era Revolusi Industri 4.0 saat ini, sudah seharusnya pihak perguruan tinggi, dosen, dan mahasiswa harus bisa saling bekerja sama terkait memahami penggunaan dan pengaplikasian Teknologi Informasi tersebut. Diharapkan juga untuk kedepannya agar mahasiswa mendapatkan pelatihan terlebih dahulu dari kampus sebelum proses pembelajaran berlangsung, terkait media e-learning apa saja yang akan digunakan selama proses pembelajaran berlangsung, agar tujuan dari pembelajaran itu tercapai. 


\section{DAFTAR PUSTAKA}

[1]. Abed, E. K., Electronic Learning and its Benefits in Education, Eurasia Journal of Mathematics, Science and Technology Education, 15(3), 2019, pp. 1-8. doi: 10.29333/ejmste/102668.

[2]. Allen, M. W. and Bingham, T., Michael Allen's Guide to e-Learning: Building Interactive, Fun, and Effective Learning Programs for Any Company. 2nd Edition, 2016, Canada: John Wiley \& Sons.

[3]. Annur, M. F. and Hermansyah, H., Analisis Kesulitan Mahasiswa Pendidikan Matematika dalam Pembelajaran Daring pada Masa Pandemi Covid-19, Paedagoria: Jurnal Kajian, Penelitian dan Pengembangan Kependidikan, 11(2), 2020, pp. 195-201. doi: 10.31764/paedagoria.v11i2.2544.

[4]. Asdar, Anugrah, A. and Talib, J., E-learning Quipper School dalam Pembelajaran Berbasis Teks, Uwais Inspirasi Indonesia, 2019, Ponorogo: Jawa Timur.

[5]. Bedford, J. et al., COVID-19: Towards Controlling Of A Pandemic, The Lancet. Lancet Publishing Group, 2020, pp. 1015-1018. doi: 10.1016/S0140-6736(20)30673-5.

[6]. Chandrawati, S. R., Pemanfaatan E-Learning Dalam Pembelajaran, Jurnal Cakrawala Pendidikan, 8(2), 2010, pp. 101-203.

[7]. Coman, C. et al., Online Teaching and Learning in Higher Education during the Coronavirus Pandemic: Students Perspective, Sustainability, 12(10367), 2020, pp. 1-24. doi: $10.3390 /$ su122410367.

[8]. Falloon, G., From Digital Literacy To Digital Competence: The Teacher Digital Competency (TDC) Framework, Educational Technology Research and Development. Springer, 68(5), 2020, pp. 2449-2472. doi: 10.1007/s11423-020-09767-4.

[9]. Ferdinand, A., Structural Equation Modelling dalam Penelitian Manajemen, 2000, Semarang: Universitas Diponegoro.

[10]. Garrison, D., E-learning in the 21st Century: A Community of Inquiry Framework for Research and Practice. 3rd edition, 2017, New York, NY: Routledge.

[11]. Ghozali, I., Structural Equation Model Concepts and Applications with AMOS 22.0 Program [in Bahasa], Edited by C. VI, 2014, Semarang: Diponegoro University Press.

[12]. Hair, J. F. et al., Multivariate Data Analysis: A Global Perspective, 7th Edition, 2010, New Jersey: Pearson Prentice Hall.

[13]. Hamid, R., Sentryo, I. and Hasan, S., Online Learning And Its Problems In The Covid-19 
Emergency Period, Jurnal Prima Edukasia, 8(1), 2020, pp. 86-95. doi: 10.21831/jpe.v8i1.32165.

[14]. He, F., Deng, Y. and Li, W., Coronavirus Disease 2019: What We Know?, Journal of Medical Virology. John Wiley And Sons Inc., 92(7), 2020, pp. 719-725. doi: 10.1002/jmv.25766.

[15]. Hutauruk, A. and Sidabutar, R., Kendala Pembelajaran Daring Selama Masa Pandemi di Kalangan Mahasiswa Pendidikan Matematika: Kajian Kualiatatif Deskriptif, SEPREN: Journal of Mathematics Education and Applied, 02(01), 2020, pp. 45-51. doi: 10.36655/SEPREN.V2I1.364.

[16]. Irwanto, Pelaksanaan Pembelajaran Online (Daring) di Program Studi Pendidikan Vokasional Teknik Elektro UNTIRTA di Masa Pandemi Covid-19, Prosiding Seminar Nasional Pendidikan FKIP, 3(1), 2020, pp. 28-44.

[17]. König, J., Jäger-Biela, D. J. and Glutsch, N., Adapting to Online Teaching during COVID-19 School Closure: Teacher Education And Teacher Competence Effects Among Early Career Teachers In Germany, European Journal of Teacher Education. Routledge, 43(4), 2020, pp. 608-622. doi: 10.1080/02619768.2020.1809650.

[18]. Latip, A., Peran Literasi Teknologi Informasi dan Komunikasi pada Pembelajaran Jarak Jauh di Masa Pandemi COVID-19, EduTeach : Jurnal Edukasi dan Teknologi Pembelajaran, 1(2), 2020, pp. 107-115.

[19]. Lick Cheok, M. and Wong, S. L., Predictors of E-Learning Satisfaction in Teaching and Learning for School Teachers: A Literature Review, International Journal, 8(1), 2015, Available at: www.e-iji.net (Accessed: 16 March 2021).

[20]. Mailizar et al., Secondary school mathematics teachers' views on e-learning implementation barriers during the COVID-19 pandemic: The case of Indonesia, Eurasia Journal of Mathematics, Science and Technology Education. Modestum LTD, 16(7), 2020, p. em1860. doi: 10.29333/EJMSTE/8240.

[21]. McLoughlin, C., What ICT-related skills and capabilities should be considered central to the definition of digital literacy?, in Bastiaens, T. and Ebner, M. (eds) Proceedings of the World Conference on Educational Multimedia, Hypermedia and Telecommunications (EDMEDIA). USA, 2011, pp. 471-475.

[22]. Nortvig, A.-M., Petersen, A. K. and Balle, S. H., A Literature Review of the Factors Influencing E-Learning and Blended Learning in Relation to Learning Outcome, Student Satisfaction and Engagement, The Electronic Journal of e-Learning, 16(1), 2018, pp. 46-55.

[23]. Ozdamar-Keskin, N., Ozata, F. Z. and Banar, K., Examining Digital Literacy Competences and 
Learning Habits of Open and Distance Learners, Contemporary Educational Technology, 6(1), 2015, pp. 74-90.

[24]. Rahayu, G. D. S. et al., Analysis of elementary school students mathematical resilience during learning during the covid 19 Pandemic, Journal of Physics: Conference Series. IOP Publishing, 1657, 2020, p. 12001. doi: 10.1088/1742-6596/1657/1/012001.

[25]. Rahmah, A., Digital Literacy Learning System for Indonesian Citizen, in Procedia Computer Science 72, 2015, pp. 94-101. doi: 10.1016/j.procs.2015.12.109.

[26]. Ramadhani, R., Desain Pembelajaran Matematika Berbasis TIK: Konsep dan Penerapan. Edited by J Simarmata, 2020, Medan: Yayasan Kita Menulis.

[27]. Ramadhani, R. et al., Platform Asesmen untuk Pembelajaran Daring: Teori \& Praktik. Edited by J. Simarmata, 2020, Medan: Yayasan Kita Menulis.

[28]. Sarker, M. F. H. et al., Use of e-learning at higher educational institutions in Bangladesh: Opportunities and challenges, Journal of Applied Research in Higher Education, 2018, doi: 10.1108/JARHE-06-2018-0099.

[29]. Simanihuruk, L. et al., E-Learning: Implementasi, Strategi \& Inovasinya,. 2019, Medan: Yayasan Kita Menulis.

[30]. Solimun, Pemodelan Persamaan Struktural Generalized Structured Component Analysis (GSCA), 2012, Semarang: Modul Pelatihan GSCA Universitas Brawijaya.

[31]. Valverde-Berrocoso, J. et al., Trends in Educational Research about e-Learning: A Systematic Literature Review (2009-2018), Sustainability, 12(5153), 2020, pp. 1-23. doi: $10.3390 /$ su12125153.

[32]. Yustanti, I. and Novita, D., Pemanfaatan E-Learning bagi Para Pendidik di Era Digital 4.0, in Prosiding Seminar Nasional Pendidikan Program Pascasarjana Universitas PGR/ Palembang, 2019, pp. 338-346. 